\title{
INTERNATIONAL DISTRIBUTIONS OF VARIABLES AFFECTING DESIRABLE VEHICLE LIGHTING
}

\author{
Michael Sivak
}

FINAL REPORT AUGUST 1988 


\section{INTERNATIONAL DISTRIBUTIONS OF VARIABLES AFFECTING DESIRABLE VEHICLE LIGHTING}

Michael Sivak, Ph.D.

The University of Michigan Transportation Research Institute Ann Arbor, Michigan 48109-2150 U.S.A.

Report No. UMTRI $-88-26$

August 1988 
Techaical Repert Decunentetican Poge

\begin{tabular}{|c|c|c|c|c|}
\hline $\begin{array}{l}\text { 1. Respoet No. } \\
\text { UMTRI-88-26 }\end{array}$ & \multicolumn{2}{|c|}{ 2. Govormion Accossion Mo. } & \multicolumn{2}{|c|}{ 3. Recipient's Corolos No. } \\
\hline \multicolumn{3}{|c|}{$\begin{array}{l}\text { 4. Tirlo and subirile } \\
\text { INTERNATIONAL DISTRIBUTIONS OF VARIABLES } \\
\text { AFFECTING DESIRABLE VEHICLE LIGHTING }\end{array}$} & \multicolumn{2}{|c|}{$\begin{array}{l}\text { 5. Report Dare } \\
\text { August } 1988 \\
\text { 6. Performing Orgenization Code } \\
302744 \\
\end{array}$} \\
\hline $\begin{array}{l}\text { 7. Aunows) } \\
\text { Michael Sivak }\end{array}$ & & & \multicolumn{2}{|c|}{$\begin{array}{l}\text { 8. Portorming Orgenizection Repoet No. } \\
\text { UMTRI -88-26 }\end{array}$} \\
\hline \multicolumn{3}{|c|}{$\begin{array}{l}\text { 9. Performing Organizotion Memo Addooss } \\
\text { The University of Michigan } \\
\text { Transportation Research Institute } \\
\text { Ann Arbor, Michigan } 48109-2150 \text { U.S.A. }\end{array}$} & \multicolumn{2}{|l|}{ 10. Wort Unit No. } \\
\hline \multicolumn{3}{|c|}{ 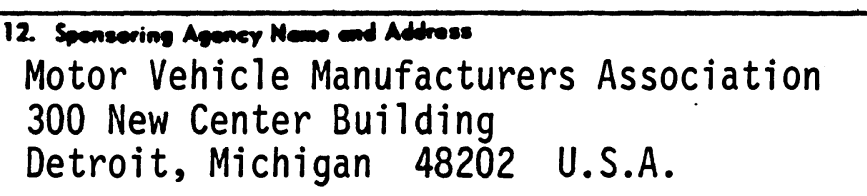 } & \multicolumn{2}{|c|}{$\begin{array}{l}\text { 13. Trreo of Roport and Poriod Covorod } \\
\text { Final Report } \\
\text { July } 1987 \text { - June } 1988\end{array}$} \\
\hline \multicolumn{5}{|l|}{ 15. Supplementery Motes } \\
\hline \multicolumn{5}{|c|}{$\begin{array}{l}\text { 16. Abstroct } \\
\text { This study was designed to provide information concerning (1) the } \\
\text { desirability of international harmonization of vehicle standards, and } \\
\text { (2) the international transferability of field-study findings on vehicle } \\
\text { lighting. Toward these goals, data were collected on a variety of factors } \\
\text { related to drivers, traffic participants, roadways, and environment in } \\
\text { eight major car-producing countries: U.S.A., Japan, Federal Republic of } \\
\text { Germany, France, Italy, Spain, Canada, and United Kingdom. The inter- } \\
\text { national variability of these factors was contrasted with the } \\
\text { correspondent variability among the U.S. states. The findings suggest } \\
\text { that, for the examined factors, the within-U.S. variability is generally } \\
\text { at least as large as the variability for the eight studied countries. } \\
\text { Consequently, it is concluded that the obtained evidence supports (1) the } \\
\text { establishment of common lighting specifications, and (2) the international } \\
\text { transferability of findings from field studies on vehicle lighting. }\end{array}$} \\
\hline $\begin{array}{l}\text { 17. Koy Woods } \\
\text { Headlighting, rear } \\
\text { roadways, vehicles, } \\
\text { regulations, specif } \\
\text { international }\end{array}$ & $\begin{array}{l}\text { ting, drivers } \\
\text { ironment, } \\
\text { ions, review, }\end{array}$ & $\begin{array}{l}\text { 18. Dia } \\
\text { Un }\end{array}$ & & \\
\hline $\begin{array}{l}\text { 19. Security Clessit. (of mis ropeos) } \\
\text { Unclassified }\end{array}$ & $\begin{array}{l}\text { 20. Socovity Clossi } \\
\text { Unclassifi }\end{array}$ & $\begin{array}{l}\text { off. (of th } \\
\text { ied }\end{array}$ & $\begin{array}{c}\text { 21. No. of Poges } \\
38\end{array}$ & 22. Price \\
\hline
\end{tabular}




\section{ACKNOWLEDGMENTS}

The support of this study by the Motor Vehicle Manufacturers Association is gratefully appreciated.

Appreciation is also extended to the following individuals for their assistance with this research:

Yosio Adachi (Public Works Research Institute, Tsukuba Science City, Japan),

Terry Birch (Transport Canada, Ottawa, Canada),

Jim Fremont (The Bicycle Foundation of America, Washington, D.C.),

Dominique Fleury (INRETS, Arcueil, France),

Kevin Kinsella (U.S. Bureau of the Census, Washington, D.C.),

Lionello Negri (Consiglio Nazionalle della Ricerche, Rome, Italy),

Paul L. Olson (University of Michigan, Ann Arbor),

R.W. Sanderson (Transport Canada, Ottawa, Canada),

Carole Simmons (University of Michigan, Ann Arbor),

Jose Soler (University of Valencia, Valencia, Spain), and

Ulrich Tränkle (University of Münster, Münster, West Germany). 
TABLE OF CONTENTS

ACKNOWLEDGMENTS $\ldots \ldots \ldots \ldots \ldots \ldots \ldots \ldots \ldots \ldots \ldots$ ii

INTRODUCTION $\ldots \ldots \ldots \ldots \ldots \ldots \ldots \ldots \ldots \ldots \ldots \ldots \ldots \ldots$

METHOD $\ldots \ldots \ldots \ldots \ldots \ldots \ldots \ldots \ldots \ldots \ldots \ldots \ldots \ldots \ldots \ldots \ldots$

FINDINGS $\ldots \ldots \ldots \ldots \ldots \ldots \ldots \ldots \ldots \ldots \ldots \ldots \ldots \ldots \ldots \ldots \ldots \ldots \ldots$

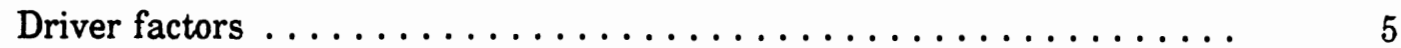

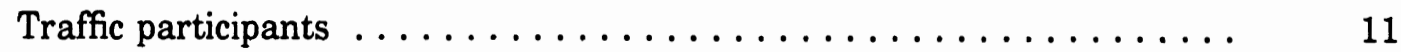

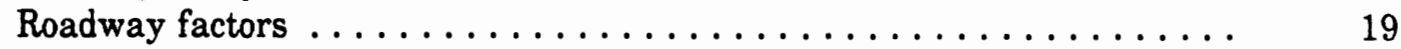

Environmental factors $\ldots \ldots \ldots \ldots \ldots \ldots \ldots \ldots \ldots \ldots \ldots \ldots$

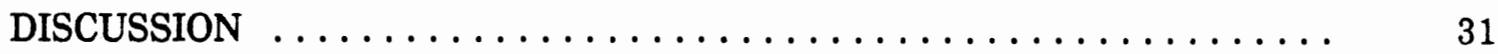

REFERENCES $\ldots \ldots \ldots \ldots \ldots \ldots \ldots \ldots \ldots \ldots \ldots \ldots \ldots \ldots \ldots \ldots \ldots$ 


\section{INTRODUCTION}

Vehicle lighting standards are substantially different in the various parts of the world. This applies to both headlighting and rear lighting standards. For example, Table 1 presents the current intensity specifications for automobile brake lamps in the U.S. and the ECE countries. It is apparent from the information in Table 1 that there is very little overlap between the two sets of specifications. Only brake lights between 80 and $100 \mathrm{~cd}$ would meet both requirements. This is too narrow a region to be of practical benefit. Consequently, the differences in the specification prevent manufacturers from producing the same brake lamps for the U.S. and European markets. This is only one of several instances of photometric differences in rear-lighting specifications. Furthermore, the situation in vehicle headlighting is even worse. The differences in the location and maximum/minimum values of various photometric test points (Olson, 1977) effectively prevent production of a "world" headlamp. (Additional differences are present for headlamp construction and aiming [Olson, 1977].)

TABLE 1

Brake-lamp photometric specifications in the U.S.A. and Europe.

\begin{tabular}{l|c|c}
\hline \multicolumn{1}{c|}{ Region } & $\begin{array}{l}\text { Minimum } \\
\text { (cd @HV) }\end{array}$ & $\begin{array}{c}\text { Maximum } \\
\text { (cd @HV) }\end{array}$ \\
\hline $\begin{array}{l}\text { USA } \\
\text { (FMVSS/SAE Specifications) }\end{array}$ & 80 & 300 \\
$\begin{array}{l}\text { Europe } \\
\text { (ECE specifications) }\end{array}$ & 40 & 100 \\
\hline
\end{tabular}

Traditional approaches to reconciling these differences in specifications have been to establish, through research, various aspects of "optimal" headlamps (e.g., Olson and Sivak, 1983) and rear lights (e.g., Sivak, Flannagan, Olson, Bender, and Conn, 1986). However, no consensus on the optimum photometrics has yet been achieved in either headlighting or rear lighting. Why is there no agreement? After an extensive review of the headlighting literature, Olson (1978) concluded that, "experimental studies have not produced a consensus on the 'best' low-beam system, partly because the test conditions have not permitted examination of all variables present in real-world night driving (p. 16)." Furthermore, as Olson (1977) has pointed out, "there are a great number of 
criteria to be considered in the design of low-beam units. Inevitably, no one design can be best measured against all criteria. The weighting of criteria is a subjective process at present and seems likely to remain so for the foreseeable future (p. 54)." The same considerations apply for rear lighting as well.

This state of affairs leads naturally to one of the basic questions underlying the present research: Are the relevant driver, vehicular, roadway, and atmospheric conditions in the various parts of the world similar enough to justify further research toward "world" lighting standards? The implicit assumption is that the answer is "yes." However, no rigorous evaluation of this assumption has ever been performed. Consequently, it is important to establish the similarities and differences in the critical conditions. It is possible that the differences are large enough, so that optimal lighting is likely to be different in various parts of the world.

The degree of worldwide similarity of the relevant conditions also has an impact on the degree of international transfer of field-study results. Should the conditions be generally different, then caution needs to exercised in transferring results from field studies performed in one country to the situation in another country.

To ascertain the feasibility of international harmonization of vehicle-headlighting standards, and the degree of transfer of field-study results, this study examined the differences in a range of relevant conditions for the following eight countries: U.S.A., Japan, West Germany ${ }^{1}$, France, Italy, Spain, Canada, and United Kingdom ${ }^{2}$. These countries were selected because they represent the eight largest passenger-car producers in the Western world (see Table 2). While the focus will be on the eight above-mentioned countries, additional comparisons will also occasionally be made with other countries (primarily those that represent the extreme values of the variables under investigation). (These eight countries also represent eight out of the top nine Western countries in the number of registered passenger cars, with Brazil being the eighth and Spain being the ninth [MVMA, 1988].)

${ }^{1}$ For brevity, "West Germany" will be used throughout this report in lieu of "Federal Republic of Germany."

${ }^{2}$ Some of the tables to follow are based on the information that was identified in the original source as pertaining to Great Britain (i.e., excluding Northern Ireland) as opposed to United Kingdom (IRF, 1986, 1987). Nevertheless, in this report the reference will always be made to United Kingdom. 
TABLE 2

The eight largest passenger-car producers in the Western world, 1986 (MVMA, 1988).

\begin{tabular}{l|c}
\hline \multicolumn{1}{c|}{ Country } & Production \\
\hline U.S.A. & $7,828,783$ \\
Japan & $7,809,909$ \\
West Germany & $4,310,828$ \\
France & $2,773,094$ \\
Italy & $1,652,452$ \\
Spain & $1,281,899$ \\
Canada & $1,061,365$ \\
United Kingdom & $1,018,962$ \\
& \\
U.S.S.R. & $1,326,000$ \\
All Countries & $32,762,338$ \\
\hline
\end{tabular}


The international variability in the relevant factors will be contrasted, whenever possible, with the variability within the U.S.A. (i.e., the variability among the states). Such comparisons will serve to qualitatively evaluate whether the within-U.S.A. variability is at least as great as the correspondent international variability. Specifically, the variability of a factor will be estimated from the range of the values for this factor. While examinations of a variety of factors will be reported, this research was limited by the availability and comparability of international data.

\section{METHOD}

The information was obtained from two general sources:

- Annual statistics published by national and international organizations.

- Individuals in the respective countries.

The range was used as an indicator of the variability of a distribution. Obviously, there is no one-to-one correspondence between the range and the variability. Nevertheless, the range data, in the absence of more detailed distributional data, provide the first approximation to the variability. 


\section{FINDINGS}

The findings are being presented in relation to four major categories of factors: drivers, traffic-participants, roadways, and environment.

\section{Driver factors}

Age. Associated with aging are changes in a range of visual, perceptual, cognitive, and psychophysical abilities (Birren and Schaie, 1985), with potential consequences for driving performance. For example, because of the increase in light scatter in older persons' eyes (Weale, 1963), the elderly generally are more impaired by glare (Wolf, 1960). This increased susceptibility to disability glare has implications for the photometric maxima of both headlights and brake lights. Consequently, when taking into account older drivers, glare considerations become dominant. As another example, older persons have generally longer reaction times (Welford, 1977). A consequence of this effect is that older drivers need to detect an obstacle at a longer distance in order to make an appropriate decision-again with important consequences for the design of headlamps. (The increased susceptibility to glare and the increased reaction time result in somewhat contradictory requirements on headlighting: When designing for the older driver, glare from the oncoming traffic should be minimized, while light output should be maximized for increasing the seeing distance. Presumably, the only currently reasonably approach to this dilemma is a sharper gradient in the light output.)

The age changes in a variety of potentially relevant functions make it important to evaluate the age distributions of drivers. The data on the percentages of older persons in the general population are shown in Table 3.

The international range of the elderly population in Table 3 should be contrasted with the corresponding range within individual countries. Such within-country distribution for one country-U.S.A. - is shown in Table 4. (Table 4 includes data for the ten most extreme states.)

The data in Tables 3 and 4 are for the total population. The optimal datapercentage of the elderly drivers - is not readily available, with the exception of the U.S.A. The U.S. data (FHWA, 1987a) indicates a good congruence between the percentage of drivers 65 years and older (12.3\%), and the corresponding percentage in the general population (12.2\% [Table 3]). 
TABLE 3

Percentage of the total population that is 65 years of age and older in selected countries; estimates and projections for 1987 (U.S. Bureau of the Census, 1988b).

\begin{tabular}{l|c}
\hline \multicolumn{1}{c|}{ Country } & $\begin{array}{c}\text { Percentage } \\
\geq 65\end{array}$ \\
\hline U.S.A. & 12.2 \\
Canada & 10.9 \\
France & 13.4 \\
Italy & 13.7 \\
Spain & 12.3 \\
United Kingdom & 15.4 \\
West Germany & 15.2 \\
Japan & 10.8 \\
& \\
Sweden & 17.8 \\
United Arab Emirates & 0.9 \\
\hline
\end{tabular}


TABLE 4

Percentage of the total population that is 65 years of age and older in selected U.S. states, 1986 (U.S. Bureau of the Census, 1988a).

\begin{tabular}{l|c}
\hline \multicolumn{1}{c|}{ State } & $\begin{array}{c}\text { Percentage } \\
\geq 65\end{array}$ \\
\hline Florida & 17.7 \\
Pennsylvania & 14.6 \\
Rhode Island & 14.6 \\
Arkansas & 14.5 \\
Iowa & 14.5 \\
& \\
Texas & 9.5 \\
Colorado & 9.0 \\
Wyoming & 8.4 \\
Utah & 8.0 \\
Alaska & 3.4 \\
\hline
\end{tabular}


Alcohol consumption. Alcohol is known to have a variety of detrimental effects on vision, decision-making, and psycho-motor performance. For example, in the area of vision, alcohol has negative effects on dynamic visual acuity (Brown, Adams, Haegerstrom-Portnoy, Jones, and Flom, 1975), and on glare sensitivity (Adams, Brown, and Flom, 1976). The impairments in basic skills are known to affect driving-performance and are assumed to contribute to accident overrepresentation of drivers under the influence of alcohol (e.g., Smiley and Brookhuis, 1987).

It is apparent that in the U.S. the enforcement efforts to prevent drunk driving have not been successful. In 1986, for example, $41 \%$ of drivers involved in fatal accidents had been drinking (UMTRI, 1988). Thus, the available countermeasures involve taking the drunk driver into account in the design of the driving environment. Areas that have been explored include, for example, optimization of traffic signs (Hicks, 1976) and road markings (Ranney and Gawron, 1986). Optimization of the headlighting pattern, in response to the impaired capabilities of drunk drivers, would fall into the same general category of countermeasures.

Because of the above considerations, the consumption of absolute alcohol per capita in various countries is shown in Table 5. In comparison, the data for the ten most extreme states within the U.S.A. are shown in Table 6. 
TABLE 5

Consumption of absolute alcohol per capita in selected countries, 1984 (Horgan, Sparrow, and Brazeau, 1986).

\begin{tabular}{l|c}
\hline Country & $\begin{array}{c}\text { Annual consumption } \\
\text { (liters per capita) }\end{array}$ \\
\hline U.S.A. & 7.90 \\
Canada & 7.98 \\
France & 14.22 \\
Italy & 11.51 \\
Spain & 10.86 \\
United Kingdom & 7.27 \\
West Germany & 11.90 \\
Japan & 5.87 \\
& \\
Luxembourg & 19.33 \\
Norway & 3.95 \\
\hline
\end{tabular}


TABLE 6

Consumption of absolute alcohol per capita in selected U.S. states, 1985.

\begin{tabular}{l|c}
\hline \multicolumn{1}{c|}{ State } & $\begin{array}{c}\text { Annual consumption } \\
\text { (liters per capita) }\end{array}$ \\
\hline Nevada & 15.60 \\
District of Columbia & 15.48 \\
New Hampshire & 14.50 \\
Alaska & 10.52 \\
Florida & 9.80 \\
Kentucky & \\
Oklahoma & 5.60 \\
Arkansas & 5.53 \\
West Virginia & 5.22 \\
Utah & 5.03 \\
\hline
\end{tabular}

Sources: Beer Institute, 1986 (consumption of distilled spirits, beer, and wine), and NIAAA, 1985 (conversions to absolute alcohol). 


\section{Traffic participants}

The composition of the traffic fleet relates to safety considerations for several reasons. One obvious reason (which is not relevant to the topic under investigation) is the effect of the composition on the variance in the mass of the traffic participants. Another reason is that the nature of the traffic fleet affects the speed distribution. As Solomon (1964) has pointed out, "the greater the differential in speed of a driver and his vehicle from the average speed of all traffic, the greater the chance of that driver being involved in an accident" (p. iii). (A refinement of this statement was offered by Cowley [1987] who concluded, on the basis of a literature review, that this did not apply to single-vehicle accidents.)

Bicycles and mopeds. On one extreme of the speed distribution are the bicyclists. Because of their slow speed, headlighting systems with long seeing distance would be especially desirable in regions with a substantial bicycle usage. With this consideration in mind, Tables 7 and 8 present international data on bicycles. Table 7 list the numbers of bicycles held, and the population per bicycle. The numbers of motor vehicles per bicycle, indicative of the respective speed distributions, are shown in Table 8. (The optimal databicycles in use-were not available.) The analogous data for mopeds (another class of relatively slow-moving traffic participants) are shown in Table 9.

Trucks and buses. Trucks and buses, because of their generally lower top speed and slower acceleration, also contribute to an increase in the variance of speed distribution. The relevant international truck and bus data are shown in Table 10. In comparison, the analogous U.S. data for the ten most extreme states are shown in Table 11.

Pedestrians. Providing sufficient illumination for the detectability of pedestrians is one of the main contemporary criteria of effective headlighting (Perel, Olson, Sivak, and Medlin, 1984). The relative weight that is placed on this performance aspect of headlamps is influenced by the incidence of pedestrians (Bhise, Farber, and McMahan, 1976). Consequently, comparison of international and domestic incidence of encounters with pedestrians would be desirable. The closest available data to this ideal are the data on the population density per $\mathrm{km}$ of the roadway. Such international data are shown in Table 12 , while the data for the ten most extreme U.S. states are in Table 13. 
TABLE 7

Number of bicycles held in selected countries (Cycle Press International, 1987).

\begin{tabular}{l|c|c}
\hline \multicolumn{1}{c|}{ Country } & $\begin{array}{c}\text { Number } \\
\text { (in millions) }\end{array}$ & $\begin{array}{c}\text { Persons } \\
\text { per bicycle }\end{array}$ \\
\hline U.S.A. (1984) & 95 & 2.4 \\
Canada (1987?) & 8 & 3.2 \\
France (1984) & 17 & 3.2 \\
Italy (1984) & 20 & 2.8 \\
Spain & $?$ & $?$ \\
United Kingdom (1982) & 14 & 4.0 \\
West Germany (1985) & 35 & 1.8 \\
Japan (1986) & 58 & 2.1 \\
India (1980) & 11 & 16.0 \\
Brazil (1981) & 42 & 10.6 \\
China (1985) & 12 & 5.0 \\
The Netherlands (1984) & 210 & 1.3 \\
\hline
\end{tabular}

a The information for Canada is based on an estimate of the number of bicycles by the Canadian Cycling Association (Sanderson, 1988). 
TABLE 8

Number of motor vehicles per bicycle in selected countries.

\begin{tabular}{l|c}
\hline \multicolumn{1}{c|}{ Country } & $\begin{array}{c}\text { Motor vehicles } \\
\text { per bicycle }\end{array}$ \\
\hline U.S.A. & 1.8 \\
Canada & 1.8 \\
France & 1.4 \\
Italy & 1.1 \\
Spain & $?$ \\
United Kingdom & 1.4 \\
West Germany & 0.8 \\
Japan & 0.8 \\
& \\
Brazil & 0.9 \\
The Netherlands & 0.5 \\
Finland & 0.3 \\
China & 0.01 \\
\hline &
\end{tabular}

Sources: Cycle Press International, 1987 (number of bicycles, with the exception of Canada), Sanderson, 1988 (number of bicycles in Canada), IRF, 1987 (number of motor vehicles with the exception of Brazil and China), IRF, 1986 (number of motor vehicles in Brazil), and CATARC, 1986 (number of motor vehicles in China). 
TABLE 9

Number of motor vehicles per moped in selected countries, 1983 (ECMT, 1985).

\begin{tabular}{|c|c|}
\hline Country & $\begin{array}{l}\text { Motor vehicles } \\
\text { per moped }\end{array}$ \\
\hline U.S.A. & $?$ \\
\hline Canada $^{a}$ & 322.6 \\
\hline France & 5.4 \\
\hline İtaly & $?$ \\
\hline Spain & $?$ \\
\hline United Kingdom & $?$ \\
\hline West Germany & 15.4 \\
\hline $\operatorname{Japan}^{2}$ & 3.5 \\
\hline Sweden & 16.6 \\
\hline The Netherlands & 8.1 \\
\hline Switzerland & 4.0 \\
\hline
\end{tabular}

$a_{1982 \text { data. }}$ 
TABLE 10

Number and proportion of trucks and buses in selected countries, 1985 (MVMA, 1988).

\begin{tabular}{l|c|c}
\hline \multicolumn{1}{c|}{ Country } & $\begin{array}{c}\text { Number of } \\
\text { trucks and buses } \\
\text { (in thousands) }\end{array}$ & $\begin{array}{c}\text { Proportion of } \\
\text { trucks and buses } \\
\text { of all motor vehicles }\end{array}$ \\
\hline U.S.A. & 39,790 & .23 \\
Canada & 3,149 & .22 \\
France & 2,766 & .11 \\
Italy & 1,824 & .08 \\
Spain & 1,610 & .15 \\
West Germany & 1,723 & .06 \\
United Kingdom & 728 & .04 \\
Japan & 18,313 & .40 \\
China & 2,374 & .82 \\
Australia & 2,132 & .24 \\
Bulgaria & 27,024 & .03 \\
All countries & & \\
\hline
\end{tabular}


TABLE 11

Number and proportion of trucks and buses in selected U.S. states, 1985 (FHWA, 1986).

\begin{tabular}{l|c|c}
\hline \multicolumn{1}{c|}{ State } & $\begin{array}{c}\text { Number of } \\
\text { trucks and buses } \\
\text { (in thousands) }\end{array}$ & $\begin{array}{c}\text { Proportion of } \\
\text { trucks and buses } \\
\text { of all motor vehicles }\end{array}$ \\
\hline Wyoming & 213 & .43 \\
Montana & 257 & .40 \\
Alaska & 133 & .38 \\
Idaho & 322 & .38 \\
South Dakota & 246 & .38 \\
Hawaii & 82 & .13 \\
Massachusetts & 470 & .13 \\
New Jersey & 495 & .10 \\
Connecticut & 158 & .06 \\
District of Columbia & 18 & .06 \\
\hline
\end{tabular}


TABLE 12

Population density per roadway network in selected countries, 1985 (IRF, 1987).

\begin{tabular}{l|c}
\hline \multicolumn{1}{c|}{ Country } & $\begin{array}{c}\text { Persons per } \\
\text { km of roadway }\end{array}$ \\
\hline U.S.A. & 38 \\
Canada & $30^{\mathrm{a}}$ \\
France & 69 \\
Italy & 189 \\
Spain & 121 \\
United Kingdom & 157 \\
West Germany & 124 \\
Japan & 107 \\
& \\
The Netherlands & 129 \\
Switzerland & 92 \\
\hline
\end{tabular}

${ }^{a_{B}}$ Based on the length of the road network provided in RTAC (1987) and the population data in IRF (1987). 
TABLE 13

Population density per roadway network in selected U.S. states, 1985.

\begin{tabular}{l|c}
\hline \multicolumn{1}{c|}{ State } & $\begin{array}{c}\text { Persons per } \\
\text { km of roadway }\end{array}$ \\
\hline District of Columbia & 351 \\
Hawaii & 166 \\
New Jersey & 139 \\
Massachusetts & 107 \\
Connecticut & 100 \\
& \\
Idaho & 9 \\
Wyoming & 8 \\
Montana & 7 \\
South Dakota & 6 \\
North Dakota & 5 \\
\hline
\end{tabular}

Sources: U.S. Bureau of the Census, 1988a (population) and FHWA, 1986 (road network). 


\section{Roadway factors}

Paved vs. unpaved roadways. There are several aspects of the roadway infrastructure that affect desirable lighting. For example, the extent of paved roads is important for glare control from vehicle headlamps. Specifically, a sharp intensity gradient is likely to be more of a problem on unpaved than paved roads. The available international data on the percentage of paved roads is shown in Table 14. However, the validity of these data is questionable, since they indicate that all roads in Italy and the United Kingdom are paved. This suggests that the roads considered for inclusion by IRF (the source of the data) might have varied from country to country. Consequently, no explicit comparison was attempted between the international data in Table 14 and withinU.S. distributions that could have been derived from the information in FHWA (1987a).

Motorways (limited-access roadways). One of the benefits of motorways is that meetings with oncoming traffic are avoided. Consequently, glare from the opposing lane of traffic is reduced. (Glare from rearview mirrors, however, still remains as a factor.) Thus, the proportion of traffic on motorways is another potentially important consideration. International data on the proportion of motorways and proportion of motorway traffic volume are listed in Table 15. The analogous data (percent vehicle-iniles on motorways) for the ten most extreme U.S. states are shown in Table 16.

Traffic density. Traffic density affects the frequency of meeting situations. (Obviously, this does not apply to motorways.) The frequency of meeting opposing vehicles, in turn, contributes to the frequency of occurrence of headlamp glare and affects the degree of dark adaptation. (The degree of dark adaptation influences the detectability of rear lights and of other targets during nighttime driving.) Table 17 presents two sets of international data on the density of traffic: vehicles per $\mathrm{km}$ of roadway, and $\mathrm{km}$ travelled per $\mathrm{km}$ of roadway. The analogous data for the ten most extreme U.S. states are listed in Table 18. 
TABLE 14

Percentage of paved roads in selected countries, 1985 (IRF, 1987).

\begin{tabular}{l|c}
\hline \multicolumn{1}{c|}{ Country } & $\begin{array}{c}\text { Paved roads } \\
(\%)\end{array}$ \\
\hline U.S.A. & 55 \\
Canada & $36^{\mathrm{a}}$ \\
France & 92 \\
Italy & $1 \mathrm{CO}$ \\
Spain & $56^{\mathrm{b}}$ \\
United Kingdom & 100 \\
West Germany & 99 \\
Japan & $56^{\mathrm{c}}$ \\
\hline
\end{tabular}

${ }^{a}$ From RTAC (1987)-includes "surface treated" roadways.

$\mathrm{b}$ Includes rural paths and forest trails.

From Road Bureau (1985). 
TABLE 15

Motorways and motorway traffic in selected countries.

\begin{tabular}{l|c|c}
\hline \multirow{2}{*}{ Country } & \multicolumn{2}{|c}{ Motorways } \\
\cline { 2 - 3 } & $\begin{array}{c}\text { \% of total } \\
\text { roadways }\end{array}$ & $\begin{array}{c}\text { \% of total } \\
\text { traffic volume }\end{array}$ \\
\hline U.S.A. & 1.3 & 20 \\
Canada & $0.9^{c}$ & $?$ \\
France & 0.8 & 16 \\
Italy & 2.0 & $?$ \\
Spain & 0.6 & 6 \\
United Kingdom & 0.8 & 26 \\
West Germany & 1.7 & 6 \\
Japan & 0.3 & 12 \\
\hline
\end{tabular}

$a_{1985}$ data except for Italy (1984) (IRF, 1987).

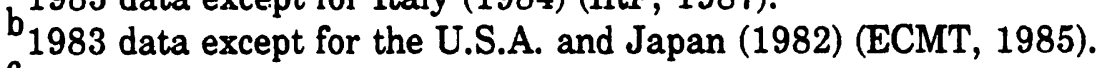

${ }^{c}$ Based on the length of the road network provided in RTAC (1987). 
TABLE 16

Percent of annual vehicle-miles on motorways in selected U.S. states, 1986 (FHWA, 1987a).

\begin{tabular}{l|c}
\hline State & $\begin{array}{c}\text { \% of total annual } \\
\text { vehicle-miles } \\
\text { travelled on motorways }\end{array}$ \\
\hline California & 39 \\
Connecticut & 38 \\
Massachusetts & 36 \\
Maryland & 33 \\
Washington & 31 \\
Maine & 17 \\
Nebraska & 17 \\
Wisconsin & 17 \\
North Dakota & 16 \\
Delaware & 15 \\
All states & 27 \\
\hline & \\
\hline & \\
\hline
\end{tabular}


TABLE 17

Density of traffic in selected countries, 1985 (IRF, 1987).

\begin{tabular}{l|c|c}
\hline \multicolumn{1}{c|}{ Country } & $\begin{array}{c}\text { Vehicles per } \\
\text { km of road }\end{array}$ & $\begin{array}{c}\text { Thousand km travelled } \\
\text { per km of road }\end{array}$ \\
\hline U.S.A. & 28 & 460 \\
Canada & $17^{\mathrm{a}}$ & $?$ \\
France & 30 & 430 \\
Italy & $75^{\mathrm{b}}$ & $922^{\mathrm{b}}$ \\
Spain & 72 & $243^{\mathrm{b}}$ \\
United Kingdom & 53 & 804 \\
West Germany & $54^{\mathrm{b}}$ & 724 \\
Japan & 41 & 456 \\
\hline
\end{tabular}

${ }_{b}^{a}$ Based on the length of the road network provided in RTAC (1987).

$b_{1984 \text { data. }}$ 
TABLE 18

Density of traffic in selected U.S. states, 1985 (FHWA, 1987b).

\begin{tabular}{|c|c|c|c|}
\hline State & $\begin{array}{c}\text { Vehicles per } \\
\mathrm{km} \text { of road }\end{array}$ & State & $\begin{array}{c}\text { Thousand } \mathrm{km} \text { travelled } \\
\text { per } \mathrm{km} \text { of road }\end{array}$ \\
\hline District of Columbia & 184 & District of Columbia & 2,925 \\
\hline Hawaii & 103 & Hawaii & 1,717 \\
\hline New Jersey & 90 & New Jersey & 1,567 \\
\hline Connecticut & 78 & Maryland & 1,209 \\
\hline Maryland & 74 & California & 1,192 \\
\hline Wyoming & 8 & Nebraska & 131 \\
\hline Idaho & 8 & Idaho & 111 \\
\hline Montana & 6 & Montana & 106 \\
\hline South Dakota & 6 & South Dakota & 86 \\
\hline North Dakota & 5 & North Dakota & 63 \\
\hline
\end{tabular}


Speed limits. Speed influences the desirable preview distance, since the stopping distance is a monotonic function of initial speed. Consequently, greater speed calls for longer visibility distance. Recent international speed limits are listed in Table 19.

TABLE 19

Speed limits in selected countries, 1984 (adapted from Fieldwick and Brown, 1987).

\begin{tabular}{|c|c|c|c|c|}
\hline \multirow{3}{*}{ Country } & \multicolumn{4}{|c|}{$\begin{array}{c}\text { General speed limit } \\
(\mathrm{km})\end{array}$} \\
\hline & \multirow[b]{2}{*}{ Urban } & \multicolumn{3}{|c|}{ Rural } \\
\hline & & $\begin{array}{l}\text { Limited-access } \\
\text { (freeways) }\end{array}$ & $\begin{array}{c}\text { Major } \\
\text { arterials }\end{array}$ & Other \\
\hline U.S.A. & 48 & $88^{a}$ & 88 & 88 \\
\hline Canada ${ }^{b}$ & $50-60$ & 100 & $80-90$ & 80 \\
\hline France & 60 & 130 & 110 & 90 \\
\hline Italy & 50 & 140 & 110 & 110 \\
\hline Spain & 60 & 100 & 90 & 80 \\
\hline United Kingdom & 48 & 112 & 112 & 97 \\
\hline West Germany & 50 & $130^{c}$ & $130^{c}$ & 100 \\
\hline Japan & $?$ & $80-100^{d}$ & $50^{\mathrm{e}}$ & $40^{\mathrm{e}}$ \\
\hline Austria & 50 & 130 & 100 & 100 \\
\hline Ireland & 48 & 97 & 97 & 97 \\
\hline Switzerland & 50 & 120 & 80 & 80 \\
\hline
\end{tabular}

$a_{105}$ since 1987.

brom Birch (1988).

cAdvisory limit only.

From IATSS (1985).

e From Koshi (1985). 
Lane/road width. The lane/road widths influence the desirable spread of the headlamp beam and the need for tight control of headlamp glare. Unfortunately, international data in a common format were not available, as illustrated in Tables 20 through 22. Table 20 shows the U.S. data for the percentages of roads with different lane widths. (The analogous breakdown by the individual U.S. states can be computed from from the data in FHWA [1987a].) Table 21 presents the Japanese data for the width of the whole roadway. The analogous data for a subset of West German roads is shown in Table 22.

TABLE 20

Distribution of U.S. roadways by lane width, 1986 (computed from the data in FHWA, 1987a).

\begin{tabular}{c|c}
\hline $\begin{array}{c}\text { Lane width } \\
\text { (feet) }\end{array}$ & $\begin{array}{c}\text { Percent of all } \\
\text { roadways }\end{array}$ \\
$<9$ & 4.8 \\
9 & 11.6 \\
10 & 24.1 \\
11 & $16.9^{\mathrm{a}}$ \\
12 & 37.4 \\
$>12$ & 5.1 \\
\hline
\end{tabular}

${ }^{\text {a Includes }} 301$ miles $(484 \mathrm{~km})$ of interstate highways classified as having a lane width of less than 12 feet. 
TABLE 21

Distribution of Japanese roadways by total width, 1984 (computed from the data in Road Bureau, 1985).

\begin{tabular}{c|c}
\hline $\begin{array}{c}\text { Road width } \\
(\mathrm{m})\end{array}$ & $\begin{array}{c}\text { Percent of } \\
\text { roadways }\end{array}$ \\
$<5.5$ & 74.3 \\
$5.5-13$ & 24.0 \\
$>13$ & 1.7 \\
\hline
\end{tabular}

TABLE 22

Distribution of West German roadways by total width, 1986 (computed from the information in Bundesminister fur Verkehr, 1987). (Urban roads not included.)

\begin{tabular}{c|c}
\hline $\begin{array}{c}\text { Road width } \\
(\mathrm{m})\end{array}$ & $\begin{array}{c}\text { Percent of } \\
\text { roadways }\end{array}$ \\
\hline$<5$ & 11.7 \\
$5-6$ & 27.6 \\
$6-7$ & 29.2 \\
$7-9$ & 19.6 \\
$9-12$ & 4.1 \\
$\geq 12$ & 7.8 \\
\hline
\end{tabular}


Road surface. Different road surfaces, because of their different reflectivities, influence the effective contrast between targets and roadway. Indicative of the practical range is the data of Bhise, Farber, Saundby, Troell, Walunas, and Bernstein (1977), who have found (using a representative sample of U.S. roadways) that the majority of dry pavement had reflectivity of $2 \%$ to $11 \%$. The only international information available-for Japan-is presented in Table 23.

TABLE 23

Distribution of roadways in Japan by surface type, 1984

(computed from the information in Road Bureau, 1985).

\begin{tabular}{c|c}
\hline Surface & $\begin{array}{c}\text { Percent of } \\
\text { roadways }\end{array}$ \\
\hline Gravel & 44.3 \\
Cement & 3.7 \\
Asphalt & 51.9 \\
\hline
\end{tabular}

Fixed illumination. Illumination from fixed sources influences the optimal aspects of vehicle lighting. A survey conducted by Bhise et al. (1977) indicates that the percentage of roads with fixed illumination varied from $1 \%$ to $8 \%$ for rural roads and $55 \%$ to $91 \%$ for urban roads (the actual percentage depending on the road type). However, no comparable international data were available. 


\section{Environmental factors}

Atmospheric conditions have substantial effects on the effectiveness of vehicle headlighting and rear lighting. For example, rain can increase glare and affect the contrast of critical objects illuminated by headlamps (Perel, Olson, Sivak, and Medlin, 1984). Similarly, fog will reduce the levels of contrast (such as between a brake light and its background), with the effect being greater during nighttime than during daytime (OECD, 1976). Consistent with the above are the findings of increased accidents (primarily at night) during rain (Haghighi-Talab, 1973) and fog (Koth, McCunney, Duerk, Janoff, and Freeman, 1978). (Visibility during and after snowfall is a more complex issue. While there might be reduced visibility during falling or blowing snow, there might be cases of improved visibility because of high contrast between dark road/objects and white snow on the sides [OECD, 1976].)

For a meaningful comparison of international differences in exposure to adverse weather, map data showing the average annual amount of rain, snow and, fog would be desirable. However, such data (in a relatively comparable format) were available only for total precipitation. Table 24 presents a summary of the precipitation data contained originally in a map form. Localized extreme values are not included in Table 24.

As was pointed out by an ad hoc OECD research group, "in most countries data on the occurrence and duration of fog is collected at meteorological centers and airports which do not provide the level of detail or extent of coverage sufficient for statistical analysis" (OECD, 1976, p. 11). The only readily available recent data in map form were for Canada (Environment Canada, 1984). (Relatively old U.S. data that might not be representative of the current conditions are contained in Visher [1954].) 
TABLE 24

Mean annual precipitation in selected countries.

(Isolated extreme values are not included.)

\begin{tabular}{l|c|c}
\hline \multirow{2}{*}{ Country } & \multicolumn{2}{|c}{ Annual precipitation } \\
& Minimum & Maximum \\
\cline { 2 - 3 } & 100 & 2,500 \\
U.S.A. & & \\
Canada & 100 & 2,400 \\
rainfall & 1,000 & 10,000 \\
snowfall & 600 & 1,600 \\
France & 600 & 1,600 \\
Italy & 400 & 1,600 \\
Spain & 600 & 2,000 \\
United Kingdom & 600 & 1,600 \\
West Germany & 800 & 2,400 \\
Japan & & \\
\hline
\end{tabular}

Sources: U.S. Environmental Data Service, 1983 (U.S.A.), Environment Canada, 1984 (Canada), WMO, 1970 (France, Italy, Spain, United Kingdom, West Germany), and Chiriin, 1977 (Japan). 


\section{DISCUSSION}

Are the ranges of the values of the lighting-related factors for the eight dominant car-producing countries at least as large as the corresponding ranges for the U.S. states? The answer to this question was sought in attempt to answer the basic question underlying this research: Are the international conditions sufficiently similar for harmonization of vehicle-lighting standards, and for international applicability of findings from field studies? Table 25 provides qualitative answers concerning the comparisons of the ranges that were examined.

The information in Table 25 indicates that the available evidence suggests that the within-U.S. ranges are generally at least as large as the corresponding ranges. for the eight countries of interest. Consequently, the present study did not find any evidence in support of unique U.S. lighting specifications. Conversely, the obtained evidence supports the establishment of international lighting specifications.

The obtained information also indicates that field studies that are performed under representative conditions (for that particular country) have a relatively high degree of general applicability to other countries. (Obviously, a study performed under very specific, localized conditions would not necessarily have international applicability. Furthermore, such study might not even have a country-wide applicability.)

The present findings apply most directly to the eight countries under investigation. However, they are likely to also apply to all West European countries, and most likely to all developed countries. (Differences between developed and developing countries in some

important aspects [e.g., proportion of older persons, motorway traffic, etc.] might be substantially greater than the corresponding within-U.S. values.) 
TABLE 25

Comparison of the ranges of the relevant factors for the countries of interest and for the U.S. states.

\begin{tabular}{|c|c|c|c|}
\hline Variable & $\begin{array}{c}\text { Were } \\
\text { international } \\
\text { data available? }\end{array}$ & $\begin{array}{c}\text { Were } \\
\text { U.S. data } \\
\text { by states } \\
\text { available? }\end{array}$ & $\begin{array}{l}\text { Is the range for } \\
\text { the U.S. states } \\
\text { at least as large } \\
\text { as the corresponding } \\
\text { international range? }\end{array}$ \\
\hline Older population & Yes & Yes & Yes \\
\hline Alcohol consumption & Yes & Yes & Yes \\
\hline Bicycles & Yes & No & $?$ \\
\hline Mopeds & Yes & No & $?$ \\
\hline Trucks and buses & Yes & Yes & Yes \\
\hline Population density & Yes & Yes & Yes \\
\hline Paved roads & Yes $^{2}$ & Yes $^{b}$ & $?$ \\
\hline Motorways & Yes & Yes & Yes(?) \\
\hline Traffic density & Yes & Yes & Yes \\
\hline Speed limits & Yes & No & Yes(?) \\
\hline Lane width & No & Yes & $?$ \\
\hline Road surface & No & No & $?$ \\
\hline Fixed illumination & No & No & $?$ \\
\hline Precipitation & Yes & Yes & Yes \\
\hline
\end{tabular}

${ }_{b}^{a}$ Of questionable validity.

${ }^{b}$ Available in FHWA (1987a), but not presented in this report. 


\section{REFERENCES}

Adams, A.J., Brown, B., \& Flom, M.C. (1976). Alcohol-induced changes in contrast sensitivity following high-intensity light exposure. American Journal of Optometry and Physiological Optics, 52, 729-735.

Bhise, V.D., Farber, E.I., \& McMahan, P.B. (1976). Predicting target-detection distance with headlights. Transportation Research Record, 611, 1-16.

Bhise, V.D., Farber, E.I., Saundby, C.S., Troell, G.M., Walunas, J.B., \& Bernstein, A. (1977). Modelling vision with headlights in a systems context. SAE Technical Paper No. 770238. Warrendale: Society of Automotive Engineers.

Birch, T. (1988). Personal communication, July 20.

Birren, J.E. \& Schaie, K.W. (Eds.). (1985). Handbook of the psychology of aging (2nd ed.). New York: Van Nostrand.

Beer Institute. (1986). Brewers almanac 1986. Washington, D.C.: Author.

Brown, B., Adams, A.J., Haegerstrom-Pokorny, G., Jones, R.T., \& Flom, M.C. (1975). Effects of alcohol and marijuana on dynamic visual acuity: I. Threshold measurements. Perception and Psychophysics, 18, 441-446.

Bundesminister für Verkehr (Ed.). Verkehr in Zahlen 1987. [Traffic in numbers 1987.] Bonn: Author.

CATARC (China Automobile Technical Research Center). (1986). The motor industry of China: 1986. Tianjin: Author.

Chiriin, K. (1977). The national atlas of Japan. Tokyo: The Japan Map Center.

Cowley, J.E. (1987). The relationship between speed and accidents: a literature review. Report No. GR/87/2. Hawthorn, Australia: Road Traffic Authority.

Cycle Press International (Japan). (1987). No. 30 (August).

ECMT (European Conference of Ministers of Transport). (1985). Statistical report on road accidents in 1983. Paris: Author.

Environment Canada. (1984). Climatic atlas climatique-Canada: a series of maps portraying Canada's climate. Ottawa: Atmospheric Environment Service.

FHWA (Federal Highway Administration). (1986). Highway statistics 1985. Washington, D.C.: U.S. Department of Transportation.

FHWA (Federal Highway Administration). (1987a). Highway statistics 1986. Washington, D.C.: U.S. Department of Transportation.

FHWA (Federal Highway Administration). (1987b). Our nation's highways. Selected facts and figures. Washington, D.C.: U.S. Department of Transportation.

Fieldwick, R. and Brown, R.J. (1987). The effects of speed limits on road casualties. Traffic Engineering \& Controh 28, 635-640. 
Haghighi-Talab, D. (1973). An investigation into the relationship between rainfall and road accident frequencies in two cities. Accident Analysis \& Prevention, 5, 343-349.

Hicks, J.A., III. (1976). An evaluation of the effect of sign brightness on the sign reading behavior of alcohol impaired drivers. Human Factors, 18, 45-52.

Horgan, M.M., Sparrow, M.D., \& Brazeau, R. (1986). International survey: alcoholic beverage taxation and control policies (6th edition). Ottawa, Canada: Brewers Association of Canada.

IATSS (International Association of Traffic and Safety Sciences). (1985). White paper on transportation safety in Japan '85. Tokyo: Author.

IRF (International Road Federation). (1986). World road statistics 1981-1985. Geneva: Author.

IRF (International Road Federation). (1987). World road statistics 1982-1986. Geneva: Author.

MVMA (Motor Vehicle Manufacturers Association). (1988). World motor vehicle data. Detroit: Author.

Koshi, M. (1985). Road safety measures in Japan. In L. Evans \& Schwing, R.C. (Eds.), Human behavior and traffic safety. New York: Plenum Press.

Koth, B.W., McCunney, W.D., Duerk, D.P., Janoff, M.S., \& Freedman, M. (1978). Vehicle fog lighting: an analytical evaluation. Report No. DOT-HS-803-442. Philadelphia: Franklin Institute Research Laboratories.

NIAAA (National Institute for Alcohol Abuse and Alcoholism). (1985). U.S. alcohol epidemiologic data reference manual, Vol. 1: U.S. apparent consumption of alcoholic beverages based on state sales, taxation, or receipt data. Washington, D.C.: U.S. Department of Health and Human Services.

OECD (Organization for Economic Co-operation and Development). (1976). Adverse weather, reduced visibility and road safety. Paris: Author.

Olson, P.L. (1977). The relative merits of different low beam headlighting systems. A review of the literature. Ann Arbor: Highway Safety Research Institute, The University of Michigan, Report No. UM-HSRI-77-55.

Olson, P.L. (1978). Illumination vs. glare: the "Catch-22" of safe headlighting. The HSRI Research Review, 8(4), 1-16.

Olson, P.L. and Sivak, M. (1983). Improved low-beam photometrics. Ann Arbor: The University of Michigan Transportation Research Institute, Report. No. UMTRI83-9.

Perel, M., Olson, P.L., Sivak, M., \& Medlin, J.W. (1984). Motor vehicle forward lighting. SAE Technical Paper No. 830565. Warrendale: Society of Automobile Engineers.

Ranney, T.A. \& Gawron, V.J. (1986). The effects of pavement edge lines on performance in a driving simulator under sober and alcohol-dosed conditions. Human Factors, 28, 511-525. 
Road Bureau (1985). Roads in Japan. Japan: Japan Road Association.

RTAC (Roads and Transportation Association of Canada). (1987). Road infrastructure study. Ottawa: Author.

Sanderson, R.W. (1988). Personal communication, May 5.

Sivak, M., Flannagan, M.J., Olson, P.L., Bender, M., \& Conn, L.S. (1986). Evaluation of brake-lamp photometric requirements. Ann Arbor: The University of Michigan Transportation Research Institute, Report No. UMTRI-86-28.

Smiley, A. \& Brookhuis, K.A. (1987). Alcohol, drugs and traffic safety. In J.A. Rothengatter and R.A. de Bruin (Eds.), Road users and traffic safety. Assen/ Maastricht, The Netherlands: Van Gorcum.

Solomon, D. (1964). Accidents on main rural highways related to speed, driver, and vehicle. Washington, D.C.: U.S. Department of Commerce, Bureau of Public Roads.

UMTRI (The University of Michigan Transportation Research Institute). (1988). FARS, 1986. UMTRI Data System Codebook. Version 129. Ann Arbor: The University of Michigan Transportation Research Institute.

U.S. Bureau of the Census. (1988a). Statistical abstract of the United States: 1988 (108th edition). Washington, D.C.: Author.

U.S. Bureau of the Census. (1988b). Unpublished estimates and projections. Washington, D.C.: Author.

U.S. Environmental Data Service. (1983). Climatic atlas of the United States. Rockville, Maryland: National Oceanic and Atmospheric Administration.

Visher, S.S. (1954). Climatic atlas of the United States. Cambridge, Massachusetts: Harvard University Press.

Weale, R.A. (1963). The aging eye. London: H.K. Lewis.

Welford, A.T. (1977). Motor performance. In J.E. Birren and K.W. Schaie (Eds.), Handbook of the psychology of aging. New York: Van Nostrand.

WMO (World Meteorological Organization). 1970. Climatic atlas of Europe. I. Maps of mean temperature and precipitation. Geneva: Author.

Wolf, E. (1960). Glare and age. Archives of Ophthalmology, 64, 502-514. 